\title{
ANTENATAL AND EARLY POSTNATAL ETIOLOGICAL VERIFICATION OF RELEVANT CONGENITAL VIRAL INFECTIOUS DISEASES
}

\author{
Vasilyev $W^{1,4}$, Grineva $A A^{1} \bowtie$, Rogozina $N^{1,3}$, Ivanova RA $^{1,2}$, Ushakova $\mathrm{GM}^{1}$ \\ ${ }^{1}$ Pediatric Research and Clinical Center for Infectious Diseases, Saint-Petersburg, Russia \\ 2 Pavlov First Saint Petersburg State Medical University, Saint-Petersburg, Russia \\ ${ }^{3}$ St. Petersburg State Pediatric Medical University, Saint-Petersburg, Russia \\ ${ }^{4}$ Mechnikov North-Western State Medical University, Saint-Petersburg, Russia
}

\begin{abstract}
Nonspecificity of clinical, laboratory and instrumental manifestations of congenital infectious diseases, including viral infections, and the diversity of methods for etiological verification of pathogens define both the need to choose the optimal approaches to the diagnosis of this pathology, and the feasibility of testing for a broad range of etiologic agents in case of suspected congenital viral infection. The analysis of current guidelines, international consensus documents issued by specialists, and published results of some studies has shown that identification of the genetic material of the pathogen with the use of amniocentesis/ cordocentesis (for cytomegalovirus and parvovirus infections) or in the birth canal (for herpes simplex infection) is the key method for antenatal etiological verification of the widespread viral infections. During the postnatal period, molecular genetic testing is combined with serological diagnosis involving determining specific immunoglobulins $M$ and $G$, as well as their avidity index.
\end{abstract}

Keywords: infections, children, pregnancy, cytomegalovirus, parvovirus, herpes viruses

Author contribution: Vasilyev W - concept, final editing; Grineva AA, Vasilyev W, Rogozina NV, Ivanova RA, Ushakova GM — raw data analysis, manuscript writing; Grineva AA - manuscript editing.

$\triangle$ Correspondence should be addressed: Alexandra A. Grineva

Professora Popova, 9, St. Petersburg, 197022; a.a.grineva@gmail.com

Received: 26.08.2021 Accepted: 12.09.2021 Published online: 25.09.2021

DOI: $10.47183 /$ mes.2021.031

\section{АНТЕНАТАЛЬНАЯ И РАННЯЯ ПОСТНАТАЛЬНАЯ ЭТИОЛОГИЧЕСКАЯ ВЕРИФИКАЦИЯ АКТУАЛЬНЫХ ВРОЖДЕННЫХ ВИРУСНЫХ ИНФЕКЦИЙ}

\author{
В. В. Васильев ${ }^{1,4}$, А. А. Гринева ${ }^{1}$, Н. В. Рогозина ${ }^{1,3}$, Р. А. Иванова ${ }^{1,2}$, Г. М. Ушакова
}

1 Детский научно-клинический центр инфекционных болезней Федерального медико-биологического агентства, Санкт-Петербург, Россия

2 Первый Санкт-Петербургский государственный медицинский университет имени И. П. Павлова, Санкт-Петербург, Россия

${ }^{3}$ Санкт-Петербургский государственный педиатрический медицинский университет, Санкт-Петербург, Россия

${ }^{4}$ Северо-западный государственный медицинский университет имени И. И. Мечникова, Санкт-Петербург, Россия

Неспецифичность клинико-лабораторных и инструментальных проявлений врожденных инфекционных заболеваний, в том числе вирусной природы, многообразие методов этиологической верификации возбудителей определяют как необходимость выбора оптимальных подходов к диагностике этой патологии, так и целесообразность обследования на широкий спектр этиологических агентов при подозрении на врожденные вирусные инфекции. На основании анализа действующих рекомендаций профессиональных сообществ, международных консенсусов специалистов, результатов отдельных опубликованных исследований показано, что ключевым способом этиологической верификации широко распространенных вирусных инфекций в антенатальномпериоде является выявление генетического материалавозбудителей при амнио-, кордоцентезе (для цитомегаловирусной ипарвовирусной инфекций), в родовых путях (для герпетической инфекции). В постнатальном периоде наряду с молекулярно-генетическим исследованием проводят серологическую диагностику с определением специфических иммуноглобулинов классов М и G и индекса их авидности.

Ключевые слова: инсекции, дети, беременность, цитомегаловирус, парвовирус, герпесвирусы

Вклад авторов: В. В. Васильев - концепция, окончательное редактирование; А. А. Гринева, В. В. Васильев, Р. А. Иванова, Г. М. Ушакова - анализ исходных материалов, написание текста; А. А. Гринева - редактирование статьи.

$\checkmark$ Для корреспонденции: Александра Александровна Гринева ул. Просрессора Попова, д. 9. г. Санкт-Петербург, 197022; a.a.grineva@gmail.com

Статья получена: 26.08.2021 Статья принята к печати: 12.09.2021 Опубликована онлайн: 25.09.2021

DOI: $10.47183 /$ mes.2021.031

Congenital viral diseases (CVDs) are the disorders associated with high mortality and often with disability, which cause substantial socio-economic damage to society [1-4].

According to ICD-10, CVDs belong to class XVI, "Certain conditions originating in the perinatal period", P35 [5].

Historically, among CVDs, rubella is the best known, the classical manifestations of which have been described by N. Gregg, the australian ophthalmologist [6]. The development of the effective vaccine, and making it accessible have led to the diagnosis of congenital rubella (congenital rubella syndrome) currently being extremely rare and practically unknown in the developed countries. According to the State reports "On the state of sanitary and epidemiological well-being of the population in the Russian Federation", a total of seven congenital rubella syndrome cases were registered in the Russian Federation in 2008-2020 [7].

Over the past decades, CVDs caused by other viruses, especially by the viruses of the herpesvirus family, have been playing an increasingly important role. It is known that representatives of almost all types can be transmitted from mother to fetus. However, the rate of such transmission and the impact on the fetus are quite different, and, with respect to a number of types, poorly understood. It is now believed that among CVDs, cytomegalovirus infection is the most common [8]. The existing data on the rate of fetal damage, caused by other viruses of this family, often vary considerably, which is probably due to the use of different research methods and heterogenous groups of the examined individuals [9-15]. 
Implementation of modern methods for the diagnosis of infections (enzyme immunoassay, chemiluminescence immunoassay, immunocytochemistry, immunohistochemistry, and molecular genetic methods) had naturally led to the conclusion that, in addition to viral infections included in the original TORCH complex (rubella, cytomegalovirus, herpes simplex virus types 1 and 2), fetal damage may be caused by other viruses, such as parvovirus B19, enteroviruses, etc. [16].

It should be noted that available official data on the incidence of infectious diseases in the Russian Federation [7] contain no records of neonatal varicella, as well as of congenital parvovirus and enterovirus infection.

Regarding the congenital infections, the timely etiological diagnosis is crucial, since it defines both the pregnancy management tactics and the possibilities of etiotropic therapy. Meanwhile, antenatal diagnosis is the most topical, since neonatal diagnosis results in the uncontrolled infectious process development in the fetus, and worsens the outcome of congenital disease [15-18].

The Federal Law No. 323-FZ of November 21, 2011 "On the Basics of Health Protection of the Citizens in the Russian Federation" [19] stipulates that from January 1, 2022 the guidelines, developed and approved in accordance with the normative document of the Ministry of Health [20], become the documents, which largely determine the range and the procedure for diagnosis and treatment interventions in Russia. In the light of the current intensive work on preparation and approval of the guidelines for a significant number of nosological forms of the diseases, including some congenital infections, the authors have considered it necessary to provide the review of the modern approaches to antenatal and neonatal etiological verification of some relevant CVDs (herpes simplex types 1 and 2, cytomegalovirus infection, parvovirus B19V infection).

\section{METHODS}

The review includes the current foreign guidelines and the international consensus documents issued by professional communities, as well as the basic (according to the authors) review papers, systematic reviews and meta-analyses. The search for information was performed in the databases in English and Russian (MEDLINE, PubMed, Scopus, Web of science, Cochrane Library, eLIBRARY, etc.), the search depth was 15 years (the references to older studies of fundamental importance are provided).

The review does not include any guidelines and consensus documents, related to perinatal aspects of HIV infection, viral hepatitis, and other viral infections, the diagnostic approach to which is reported in the SanPin Sanitary Rules and Regulations 3.3686-21 "Sanitary and Epidemiological Requirements for Communicable Diseases Prevention" [20]; the papers, related to perinatal aspects of CVDs, the guidelines on which are temporary or non-legislative (COVID-19 and Zika virus disease), and the papers, substantiating the choice of the methods and instruments, included in the guidelines (this has been done by the developers of the guidelines and consensus documents).

\section{Common approaches to antenatal etiological diagnosis of CVDs}

Antenatal etiological diagnosis can be roughly divided into two stages. The first stage ("screening" stage) involves identifying the signs of probable congenital infection by non-invasive methods (in this context, by methods, preserving the integrity of the amniotic membrane). At this stage, laboratory testing of body fluids (mostly blood, urine, saliva) of the pregnant woman is used in order to detect the genetic material or the antigens of microorganisms, or to reveal the markers of immune response (specific antibodies, antibody avidity determination), together with the imaging methods (most frequently various modifications of fetal ultrasound). Virological method (culturing viruses in a cell culture with subsequent identification) is seldom applied in practice due to its labour-intensity and timeconsuming nature [21]. At this stage, one can form a wellinformed opinion whether mother has some infectious disease, and assess the condition of the fetus, but he/she is unable to answer the question concerning the presence of congenital infectious disease in the fetus.

The second stage of the antenatal diagnosis ("expert" stage) is to prove or disprove the presence of certain infectious disease in the fetus, i.e. to establish a nosological diagnosis, specifying the etiology, which is decisive for the further pregnancy and childbirth management tactics. At this stage, the invasive procedures are performed aimed at obtaining the fetal biological samples (amniocentesis, cordocentesis) and assessing the samples in order to detect the genetic material of the microorganisms, isolate the pathogen, etc. (this paper does not address the issue of the chorionic villus sampling value for the diagnosis of CVDs).

Cordocentesis and amniocentesis are limited not only by the gestational age, but also by the age of infectious process in the pregnant woman, which reduces their diagnostic value in terms of the fetal disease duration (in case the pathogen has been transmitted). Therefore, in the modern antenatal diagnosis, great importance is attached to the screening stage and to the continuous improvement of screening.

\section{Diagnosis of congenital infection caused by herpes simplex virus types 1 and 2}

Genital herpes is one of the most common sexually transmitted infections, most often caused by the herpes simplex virus type 2 (up to $85 \%$ ) [9, 11, 22]. Fetal infection occurs mainly after the neonate contacts with the virus when passing through the birth canal [23-30].

Herpes simplex virus type 2 (HSV-2) is mainly transmitted through sexual intercourse, the infection is most often acquired at the age of 20-30 years. WHO estimates that $13 \%$ of the global population aged 15-49 have this infection [9]. Various studies and reviews estimate that the prevalence of HSV-2 among pregnant women is $20-30 \%$. Furthermore, about $10 \%$ of women seronegative for HSV-2 live with seropositive partners and therefore are at risk of being infected with genital herpes during pregnancy $[23,24,30,31]$. Among serodiscordant couples, women seronegative (having no antibodies) for herpes simplex virus type 1 (HSV-1) antigens have the probability of seroconversion of $3.7 \%$; in women seropositive for antibodies to HSV-1 antigens, the risk of seroconversion for HSV-2 is estimated at $1.7 \%[23,24,30,31]$.

The risk of congenital infection is defined by the time of primary maternal infection in relation to the conception, as well as by the fact of the infection reactivation during pregnancy. It is generally accepted that the risk of transmission in case of primary maternal infection in pregnancy is up to $50 \%$, and in case of reactivation the risk is about 4\% [9].

HSV transmission occurs in utero, intrapartum and postpartum. It is believed that in $75-85 \%$ of cases, fetal infection occurs just before labour after the rupture of membranes, or intrapartum when passing through the infected birth canal. The proportion of intrauterine infection is $5-8 \%$ of neonatal 
Table. Ultrasound signs of congenital CMVI in the antenatal period [39, 40]

\begin{tabular}{|l|r|}
\hline \multicolumn{1}{|c|}{ Signs } & \multicolumn{1}{|c|}{ Rate, \% } \\
\hline Intracranial calcification & 0.6-17.4 \\
\hline Microcephaly & $4.5-13$ \\
\hline Hyperechoic bowel & $1.9-13$ \\
\hline Intrauterine growth restriction & 11.6 \\
\hline Subependymal cysts & $4.5-1.5$ \\
\hline Ventriculomegaly & 8.7 \\
\hline Ascites & 7.2 \\
\hline Pericardial effusion & 4.3 \\
\hline Hyperechoic kidneys & \\
\hline Enlarged liver & 4.3 \\
\hline Thick placenta or placental calcification & 4.3 \\
\hline Hepatic calcification & 1.4 \\
\hline Hydrops fetalis & \\
\hline
\end{tabular}

herpes cases [24-28, 30, 31]. The risk of neonatal infection varies between $30-50 \%$ for HSV infection occurring during late pregnancy (last trimester); infection in early pregnancy poses a risk of about $1 \%[11,24,25,29]$.

\section{Antenatal diagnosis of congenital infection caused by HSV type 1 and 2}

Screening in pregnancy aimed to define antibodies to herpes simplex virus in the blood is not recommended, regardless of the history of HSV infection symptoms [25-28, 30].

Assessment of pregnant women is recommended in case of the primary HSV-2 infection acquired during the first two trimesters of pregnancy. In this case, it is necessary to assess the dynamic changes in the levels of IgM, IgG to HSV-2 with an interval of 2-4 weeks in order to reveal seroconversion, as well as to perform a series of molecular genetic tests (polymerase chain reaction, $\mathrm{PCR}$ ) in order to detect HSV-2 DNA in the vaginal discharge of the pregnant woman, starting from the 32nd week of gestation, to define the tactics for delivery and to find the solution to the question of prescribing antiviral therapy. In case of primary HSV-2 infection development during the last 4-6 weeks of gestation, the risk of vertical transmission and infected neonate is high (41\%). In such a case, it is recommended to consider the possibility of cesarean delivery and prescribing etiotropic therapy to both mother and neonate [26, 28, 29].

According to the authors of this article, obligatory etiotropic treatment with direct-acting antiviral agents (acyclovir) in patients with herpes simplex in late pregnancy makes it possible to avoid transabdominal invasive procedures aimed at diagnosis/exclusion of fetal damage, recommended in patients with some other infectious diseases (see below).

\section{Neonatal diagnosis of congenital infection caused by HSV type 1 and 2}

Clinical features of neonatal herpes are diverse and nonpathognomonic, which in a number of cases makes the diagnosis difficult. The main manifestations, suggesting the presence of herpes simplex in children below the age of 6 weeks are as follows: rashes in the form of mucocutaneous vesicles, sepsis-like illness, cerebrospinal fluid pleocytosis, seizures, focal neurologic signs, respiratory distress syndrome, episodes of apnea, progressive pneumonitis, thrombocytopenia, conjunctivitis, signs of hepatitis or liver failure, elevated transaminase levels, radiographic signs of brain damage [28, 29].
In the current context, the main method of etiological verification used in such situations involves detecting the viral genetic material by PCR. Swab specimens from the mouth, nasopharynx, conjunctivae, and anus ("surface cultures"), cerebrospinal fluid samples in case of CNS involvement, additional blood samples in case of generalized forms of the disease, and print smears of the contents of vesicles should be obtained. Although the cytopathic effect of the herpes simplex virus becomes obvious during the first five days of culturing, and virological method enables typing of virus strains, such assessment is time-consuming, expensive and lacks practical applicability [29-32].

\section{Diagnosis of congenital cytomegalovirus infection}

The highest risk of fetal cytomegalovirus (CMV) infection and the development of severe forms of the disease are observed when the pregnant woman acquires primary cytomegalovirus infection (CMVI) (up to $30 \%$ of pregnant women are seronegative). The prevalence of primary $\mathrm{CMVI}$ in pregnant women reaches $1 \%$ $[33,34]$.

\section{Antenatal diagnosis of cytomegalovirus infection}

Primary maternal CMVI in pregnancy is difficult to suspect due to scarcity of symptomatic forms and nonspecific symptoms (acute respiratory illness with mildest catarrhal symptoms, multifocal lymphadenitis, hepatomegaly and splenomegaly). Ultrasound signs of possible fetal damage are also nonspecific (Table).

Currently, the routine testing of the specific lgM and lgG, the avidity of the latter (quantification in the blood serum), and the viral load (PCR) is not recommended [35-38]. These methods are feasible only in women from the risk groups: under 25 years of age, with signs of acute respiratory illness before week 20 of gestation, multiparous women having organized children, working in children's educational institutions (i.e., being at high risk of infection) [35-38].

Whenever the laboratory, clinical and instrumental signs of primary CMVI (latent viral reactivation, superinfection) are found, assessing the amniotic fluid obtained using amniocentesis (performed on or after the $6^{\text {th }}$ week since the estimated time of the disease onset and not earlier than on the $20^{\text {th }}$ week of gestation) by PCR is indicated. Cordocentesis is not recommended, because, according to the authors of the guidelines and consensus documents, this procedure has no 
advantage over amniocentesis in the diagnosis of congenital CMVI [36-38, 41].

In the case that amniocentesis is impossible (or the informed refusal is obtained from the pregnant woman), or in the case of no signs of congenital CMVI detected during the first fetal ultrasound, the repeated screening fetal ultrasounds shall be performed every 2-3 weeks [36-38, 41].

The signs of congenital CMVI progression identified by fetal ultrasound can be considered the indication for terminating a pregnancy for medical reasons [35, 36, 38].

\section{Postnatal diagnosis of cytomegalovirus infection}

The indications for laboratory and instrumental examination, aimed to exclude/verify congenital CMVI in the newborn, are as follows: the baby showing clinical signs of congenital infection regardless of their possible etiology (including leukopenia, thrombocytopenia, elevated of hepatic transaminases and direct bilirubin); failure to pass the hearing screen; the documented primary maternal $\mathrm{CMVI}$ during pregnancy regardless of the presence or absence of clinical manifestations in the baby; subfebrile temperature, maternal influenza-like illness during the first 20 weeks of gestation; threatened preterm labour; preterm birth, intrauterine growth restriction; genetic material of the pathogen identified in the afterbirth by PCR; signs of intrauterine infection detected during the radiological examination [36, 38, 39].

Identification of the CMV DNA in saliva, urine, and blood during the first three weeks of life is the method of choice for etiological verification of the disease in case of suspected congenital CMVI in the neonate. Saliva (buccal swab can be collected) and urine testing are optimal, and blood testing is less optimal [36, 38, 41-44]. Cerebrospinal fluid is assessed only in case of CNS involvement and lumbar puncture performed with the use of molecular genetic method, involving identification of the CMV DNA. Simultaneous quantification of the CMV IgM and IgG levels in the blood serum, obtained from neonates, is a more affordable, but a less informative method: specific IgM in the first days of life should indicate the primary infection. However, these are not always found in babies with congenital CMVI; false positive results also occur [45]. The high-titer specific IgG antibodies are often found in neonates, however, the concentration of antibodies transferred across the placenta is reduced during the first three weeks of life [36, 38, 45, 46].

\section{Diagnosis of congenital infection caused by human parvovirus B19}

Human parvovirus B19 infection (HPV) in pregnancy increases the risk of fetal loss, spontaneous abortion and stillbirth. The risk of adverse pregnancy outcomes reaches $10 \%$. The maternal infection acquired during pregnancy leads to fetal infection in $24-51 \%$ of cases $[49,50]$.

In the majority of cases, when parvovirus infection occurs during pregnancy, the fetus is not affected. However, infection may result in non-immune fetal hydrops due to severe anemia, congestive heart failure and myocarditis, which, with delayed diagnosis and treatment, leads to perinatal loss. The most sensitive period in terms of fetal exposure to human parvovirus B19 (B19V) is the period between 11 and 23 weeks of gestation. The fetal mortality rate in case of infection acquired before 20 weeks of gestation is about $17 \%$, and in case of infection during the later stages this value is about $6 \%$. However, infection acquired during the $3^{\text {rd }}$ trimester can result in intrauterine fetal death without any signs of non-immune hydrops and anemia in $7.5 \%$ of cases [51-54].

\section{Antenatal diagnosis of parvovirus B19 infection}

About $40 \%$ women of childbearing age are seronegative for parvovirus and are therefore susceptible to infection. Approximately $50 \%$ of the infected pregnant women are asymptomatic, they develop no classic rash of erythema infectiosum, which is found in children. Atypical symptoms, such as arthralgia, are more frequent in adults than in children.

Testing for HPV is not regulated anywhere in the world and is merely advisory. It is worth noting that screening each and every pregnant woman both for HPV and CMVI is not recommended by professional communities. Identification of non-immune hydrops fetalis or fetal death is the only indication for testing the pregnant woman for parvovirus B19 [49, 51].

Enzyme-linked immunosorbent assay for assessment of specific IgM, IgG antibodies in blood serum of pregnant women is used as a screening laboratory test. While the existence of IgG confirms the past infection, any non-negative response to immunoglobulin $\mathrm{M}$ (positive or equivocal lgM test result) would require mandatory molecular genetic testing, involving identification of parvovirus B19 DNA in woman's blood, and the infectious diseases specialist consultation in the future [51-54].

In case of acute maternal HPV infection confirmed by laboratory tests (positive IgM antibody to parvovirus B19V, presence of parvovirus B19 DNA in blood), the constant fetal monitoring with the use of Doppler ultrasonographic assessment of the peak velocity of systolic blood flow in the middle cerebral artery for the diagnosis of fetal anemia and hydrops fetalis performed every 1-2 weeks for 12 weeks is indicated [55]. If ultrasound signs of non-immune hydrops fetalis are detected, the pregnant woman should be hospitalized at the specialized obstetric unit in order to perform amniocentesis or cordocentesis (after 18-20 weeks). If severe fetal anemia is suspected based on the Doppler ultrasound data, cordocentesis is preferred $[51,56]$.

\section{Postnatal diagnosis of parvovirus B19 infection}

The indications for laboratory and instrumental examination required to exclude/verify the congenital HPV infection in the neonate are almost the same as indications for testing for other CVDs (for example, CMVI). Diagnostic approaches are also similar: molecular genetic method (PCR) is the main method of etiological verification, the whole blood and its derivatives are used as a substrate [51, 56, 57]. Other clinical and laboratory tests are performed when clinically indicated.

\section{CONCLUSION}

The list of congenital infections goes well beyond the components of TORCH-complex. Currently, there are more than 50 microorganisms capable of causing fetal damage.

Antenatal etiological verification of infections (combined with neonatal verification) is the most important instrument to define the pregnancy and childbirth management tactics, and to assess the prospects for development of the fetus and the neonate. Today, the accurate verification of the pathogen in the fetus involves invasive interventions, which limits the feasibility of those to a certain extent.

Scientific research in the field of congenital infections is, among other things, following the path of studying the 
potential of using both qualitative and quantitative methods for assessment of various infectious process markers, which is, for example, reflected in proposals to optimize testing the HIV- positive pregnant women for CMVI $[58,59]$. Perhaps in the near future such approaches would become more extensively used, especially in the situations related to mixed infections.

\section{References}

1. Grosse SD, Leung J, Lanzieri TM. Identification of congenital CMV cases in administrative databases and implications for monitoring prevalence, healthcare utilization, and costs. Curr Med Res Opin. 2021 May; 37 (5): 769-79. PubMed PMID: 33591223.

2. Grosse SD, Dollard SC, Ortega-Sanchez IR. Economic assessments of the burden of congenital cytomegalovirus infection and the cost-effectiveness of prevention strategies. Semin Perinatol. 2021; 45 (3): 151393. PubMed PMID: 33551180.

3. Lieu JEC, Kenna M, Anne S, Davidson L. Hearing Loss in Children: a review. JAMA. 2020; 324 (21): 2195-205. PubMed PMID: 33258894.

4. Velasco-Velásquez S, Celis-Giraldo D, Botero Hincapié A, Alejandro Hincapie Erira D, Sofia Cordero López S, Marulanda Orozco N, et al. Clinical, Socio-economic and Environmental Factors Related with Recurrences in Ocular Toxoplasmosis in Quindío, Colombia. Ophthalmic Epidemiol. 2021; 28 (3): 258-64. PubMed PMID: 33115293.

5. MKB 10 - Mezhdunarodnaja klassifikacija boleznej 10-go peresmotra versija: 2019. Dostupno po ssylke: https://mkb-10. com/index.php?pid=15190 (08.09.2021). Russian.

6. Gregg, NM. Congenital Cataract Following German Measles in the Mother. Epidemiol Infect. 1991; 107 (1): iii-xiv.

7. Federal'naja sluzhba po nadzoru v sfere zashhity prav potrebitelej i blagopoluchija cheloveka. Razdel «Dokumenty». Dostupno po ssylke: https://www.rospotrebnadzor.ru/documents/documents. php (08.09.2021). Russian.

8. Moodley A, Payton KSE. The Term Newborn: Congenital Infections. Clin Perinatol. 2021; 48 (3): 485-511. PubMed PMID: 34353577 .

9. World Health Organization. 2017. [2019-05-07]. Herpes simplex virus. Available from: https://www.who.int/news-room/factsheets/detail/herpes-simplex-virus.

10. Van Der Pol B. Type-specific detection of herpes simplex virus type 1 and type 2 using the cobas ${ }^{\oplus}$ HSV 1 and 2 test on the cobas $^{\circledast} 4800$ platform. Expert Rev Mol Diagn. 2016 ; 16 (11): 1145-54. PubMed PMID: 27687862.

11. James SH, Kimberlin DW. Neonatal herpes simplex virus infection: epidemiology and treatment. Clin Perinatol. 2015; 42 (1): 47-59. PubMed PMID: 25677996.

12. Tan MP, Koren G. Chickenpox in pregnancy: revisited. Reprod Toxicol. 2006 ; 21 (4): 410-20. PubMed PMID: 15979274.

13. Smith CK, Arvin AM. Varicella in the fetus and newborn. Semin Fetal Neonatal Med. 2009; 14 (4): 209-17. PubMed PMID: 19097954.

14. Sauerbrei A, Wutzler P. Neonatal varicella. J Perinatol. 2001 Dec; 21 (8): 545-9. PubMed PMID: 11774017.

15. Trotta M, Borchi B, Niccolai A, Venturini E, Giaché S, Sterrantino G, et al. Epidemiology, management and outcome of varicella in pregnancy: a 20-year experience at the Tuscany Reference Centre for Infectious Diseases in Pregnancy. Infection. 2018 Oct; 46 (5): 693-9. PubMed PMID: 29766472.

16. Auriti C, De Rose DU, Santisi A, Martini L, Piersigilli F, Bersani I, et al. Pregnancy and viral infections: Mechanisms of fetal damage, diagnosis and prevention of neonatal adverse outcomes from cytomegalovirus to SARS-CoV-2 and Zika virus. Biochim Biophys Acta Mol Basis Dis. 2021 Oct 1; 1867 (10): 166198. PubMed PMID: 34118406.

17. Peyron F, Mc Leod R, Ajzenberg D, Contopoulos-loannidis D, Kieffer F, Mandelbrot L, et al. Congenital Toxoplasmosis in France and the United States: One Parasite, Two Diverging Approaches. PLoS Negl Trop Dis. 2017 Feb 16; 11 (2): e0005222. PubMed PMID: 28207736.

18. Albright CM, Werner EF, Hughes BL. Cytomegalovirus Screening in Pregnancy: A Cost-Effectiveness and Threshold Analysis. Am J Perinatol. 2019 Jun; 36 (7): 678-87. PubMed PMID: 30567003.
19. Federal'nyj zakon ot 21 nojabrja 2011 g. N 323-FZ «Ob osnovah ohrany zdorov'ja grazhdan v Rossijskoj Federacii» s izmenenijami i dopolnenijami. https://base.garant.ru/12191967/ (Dostup 26.03.2021 g.). Russian.

20. Prikaz Ministerstva zdravoohranenija Rossijskoj Federacii ot 28.02.2019 \# 104n «Ob utverzhdenii porjadka i srokov odobrenija i utverzhdenija klinicheskih rekomendacij, kriteriev prinjatija nauchno-prakticheskim sovetom reshenija ob odobrenii, otklonenii ili napravlenii na dorabotku klinicheskih rekomendacij libo reshenija ob ih peresmotre». Dostupno po ssylke: https://www. garant.ru/products/ipo/prime/doc/72599420/. (Data obrashhenija: 12.03.2020). Russian.

21. Postanovlenie Glavnogo gosudarstvennogo sanitarnogo vracha Rossijskoj Federacii ot 28 janvarja 2021 goda \# 4 « «Sanitarno-jepidemiologicheskie trebovanija po profilaktike infekcionnyh boleznej»». Dostupo po ssylke: https://docs.cntd.ru/ document/573660140 (07.09.2021). Russian.

22. LeGoff $J$, Péré H, Bélec L. Diagnosis of genital herpes simplex virus infection in the clinical laboratory. Virol J. 2014; 11: 83. PubMed PMID: 24885431.

23. Pinninti SG, Kimberlin DW. Preventing herpes simplex virus in the newborn. ClinPerinatol. 201441 (4): 945-55. PubMed PMID: 25459782.

24. Brown ZA, Selke S, Zeh J, et al. The acquisition of herpes simplex virus during pregnancy. N Engl J Med. 1997; 337 (8): 509-15.

25. Management of Genital Herpes in Pregnancy: ACOG Practice Bulletinacog Practice Bulletin, Number 220. Obstet Gynecol. 2020 May; 135 (5): e193-e202. PubMed PMID: 32332414.

26. Samies NL, James SH. Prevention and treatment of neonatal herpes simplex virus infection. Antiviral Res. 2020 Apr; 176: 104721. PubMed PMID: 32044154.

27. Grupo de Trabajo de Infección Neonatal por virus herpes simplex de la Sociedad Española de InfectologíaPediátrica. Guía de la Sociedad Española de InfectologíaPediátricasobreprevenci ón, diagnóstico y tratamiento de la infección neonatal por virus herpes simplex [The Spanish Society of Paediatric Infectious Diseases guidelines on the prevention, diagnosis and treatment of neonatal herpes simplex infections]. An Pediatr. 2018 Jul; 89 (1): 64.e1-64.e10. PubMed PMID: 29453157.

28. Sénat MV, Anselem $O$, Picone $O$, Renesme $L$, Sananès $N$, Vauloup-Fellous $\mathrm{C}$, et al. Prevention and management of genital herpes simplex infection during pregnancy and delivery: Guidelines from the French College of Gynaecologists and Obstetricians (CNGOF). Eur J Obstet Gynecol Reprod Biol. 2018 May; 224: 93-101. PubMed PMID: 29571124.

29. Ramgopal S, Wilson PM, Florin TA. Diagnosis and Management of Neonatal Herpes Simplex Infection in the Emergency Department. PediatrEmerg Care. 2020 Apr; 36 (4): 196-202. PubMed PMID: 32265379.

30. Fernandes ND, Arya K, Ward R. Congenital Herpes Simplex. In: StatPearls Treasure Island (FL): Stat Pearls Publishing, 2021 Jan. PubMed PMID: 29939674.

31. Shangase N, Kharsany ABM, Ntombela NP, Pettifor A, McKinnon LR. A Systematic Review of Randomized Controlled Trials of School Based Interventions on Sexual Risk Behaviors and Sexually Transmitted Infections Among Young Adolescents in Sub-Saharan Africa. AIDS Behav. 2021 Mar 27. PubMed PMID: 33772695.

32. Otto WR, Myers AL, LaRussa B, Kimberlin DW, Jackson MA. Clinical Markers and Outcomes of Neonates With Herpes Simplex Virus Deoxyribonucleic Acid Persistence in Cerebrospinal Fluid in Disseminated and Central Nervous System Infection. J Pediatric Infect Dis Soc. 2018 May 15; 7 (2): e30-e33. PubMed PMID: 28510722. 
33. Davis NL, King CC, Kourtis AP. Cytomegalovirus infection in pregnancy. Birth Defects Res 2017; 109 (5): 336-464.

34. Mussi-Pinhata MM, Yamamoto AY, Aragon DC, et al Seroconversion for Cytomegalovirus Infection During Pregnancy and Fetal Infection in a Highly Seropositive Population: "The BraCHS Study". J Infect Dis. 2018; 218: 1200.

35. Hughes BL, Gyamfi-Bannerman C. Society for Maternal-Fetal Medicine (SMFM). Diagnosis and antenatal management of congenital cytomegalovirus infection. Am J Obstet Gynecol. 2016; 214 (6): B5-B11.

36. Rawlinson WD, Boppana SB, Fowler KB, Kimberlin DW, et al. Congenital cytomegalovirus infection in pregnancy and the neonate: consensus recommendations for prevention, diagnosis, and therapy. Lancet Infect Dis. 2017; 17 (6): e177-e188.

37. Britt WJ. Congenital human cytomegalovirus infection and the enigma of maternal immunity. J Virol 2017; 91 (15).

38. Luck SE, Wieringa JW, Blázquez-Gamero D, Henneke P, Schuster K, Butler K, et al. Congenital Cytomegalovirus: A European Exper Consensus Statement on Diagnosis and Management. Pediat Infect Dis J. 2017; 36 (12): 1205-13. PubMed PMID: 29140947.

39. Capretti MG, Lanari M, Tani G, Ancora G, Sciutti R, Marsico C, et al. Role of cerebral ultrasound and magnetic resonance imaging in newborns with congenital cytomegalovirus infection. Brain Dev. 2014; 36 (3): 203-11. PubMed PMID: 23647916

40. de Vries LS, Gunardi H, Barth PG, Bok LA, Verboon-Maciolek MA, Groenendaal F. The spectrum of cranial ultrasound and magnetic resonance imaging abnormalities in congenital cytomegalovirus infection. Neuropediatrics. 2004 Apr; 35 (2): 113-9. PubMed PMID: 15127310

41. Desveaux C, Klein J, Leruez-Ville M, et al. Identification of symptomatic fetuses infected with cytomegalovirus using amniotic fluid peptide biomarkers. PloSPathog. 2016; 12: e1005395.

42. Boppana SB, Ross SA, Shimamura M, Palmer AL, Ahmed A, Michaels MG, et al. Saliva polymerase-chain-reaction assay for cytomegalovirus screening in newborns. N Engl J Med. 2011; 364 (22): 2111-8. PubMed PMID: 21631323.

43. Ross SA, Ahmed A, Palmer AL, Michaels MG, Sánchez PJ, Bernstein DI, et al. Detection of congenital cytomegalovirus infection by real-time polymerase chain reaction analysis of saliva or urine specimens. J Infect Dis. 2014; 210 (9): 1415-8. PubMed PMID: 24799600

44. Eventov-Friedman S, Manor H, Bar-Oz B, Averbuch D, Caplan O, Lifshitz A, et al. Saliva Real-Time Polymerase Chain Reaction for Targeted Screening of Congenital Cytomegalovirus Infection. J Infect Dis. 2019; 220 (11): 1790-6. PubMed PMID: 31310307.

45. Bilavsky E, Watad S, Levy I, Linder N, Pardo J, Ben-Zvi H, et al. Positive IgM in Congenital CMV Infection. Clin Pediatr (Phila). 2017; 56 (4): 371-75. PubMed PMID: 28006975.

46. Rogozina NV, Vasilev W, Grineva AA, Mihailov AV, Kashtanova TA, Romanovskij AN, i dr. Ante- i postnatal'naja diagnostika i kompleksnoe lechenie vrozhdennoj citomegalovirusnoj infekcii. Ros vestn perinatol i pediatr 2019; 64: (6): 89-93. DOl: 10.21508/1027-4065-2019-64-6-89-93. Russian.

\section{Литература}

1. Grosse SD, Leung J, Lanzieri TM. Identification of congenital CMV cases in administrative databases and implications for monitoring prevalence, healthcare utilization, and costs. Curr Med Res Opin. 2021 May; 37 (5): 769-79. PubMed PMID: 33591223.

2. Grosse SD, Dollard SC, Ortega-Sanchez IR. Economic assessments of the burden of congenital cytomegalovirus infection and the cost-effectiveness of prevention strategies. Semin Perinatol. 2021; 45 (3): 151393. PubMed PMID: 33551180.

3. Lieu JEC, Kenna M, Anne S, Davidson L. Hearing Loss in Children: a review. JAMA. 2020; 324 (21): 2195-205. PubMed PMID: 33258894

4. Velasco-Velásquez $S$, Celis-Giraldo D, Botero Hincapié A, Alejandro Hincapie Erira D, Sofia Cordero López S, Marulanda Orozco N, et al. Clinical, Socio-economic and Environmental Factors Related with Recurrences in Ocular Toxoplasmosis in
47. Marsico C, Kimberlin D. W. Congenital Cytomegalovirus infection: advances and challenges in diagnosis, prevention and treatment. Ital J Pediatr. 2017; 43: 38. Published online 2017 Apr 17. DOl: 10.1186/s13052-017-0358-8.

48. Ross SA, Ahmed A, Palmer AL, Michaels MG, Sánchez PJ, Bernstein DI, et al. Detection of Congenital Cytomegalovirus Infection by Real-Time Polymerase Chain Reaction Analysis of Saliva or Urine Specimens. The Journal of Infectious Diseases 2014; 210: 1415-8. DOI: 10.1093/infdis/jiu263.

49. Xiong YQ, Tan J, Liu YM, He Q, Li L, Zou K, et al. The risk of maternal parvovirus B19 infection during pregnancy on fetal loss and fetal hydrops: A systematic review and meta-analysis. J ClinVirol. 2019; 114: 12-20. PubMed PMID: 30897374.

50. Shishko GA, Ermolovich MA, Samojlovich EO, Artyushevskaja MV, Leonova EYu, Ustinovich YuA. Rol' parvovirusnoj infekcii $v$ perinatal'noj patologii. Reproduktivnoe zdorov'e. Vostochnaja Evropa. 2015; 5: 95-102. Russian.

51. Attwood LO, Holmes NE, Hui L. Identification and management of congenital parvovirus B19 infection. Prenat Diagn. 2020 Dec; 40 (13): 1722-31. PubMed PMID: 32860469.

52. Salbetti MB, Pedranti MS, Barbero P, Molisani P, Lazzari M, Olivera N, et al. Molecular screening of the human parvoviruses B19 and bocavirus 1 in the study of congenital diseases as applied to symptomatic pregnant women and children. Access Microbiol. 2019; 1 (5): e000037. PubMed PMID: 32974527.

53. Hunter LA, Ayala NK. Parvovirus B19 in Pregnancy: A Case Review. J Midwifery Womens Health. 2021; 66 (3): 385-90. PubMed PMID: 34101977.

54. Gallinella G. The clinical use of parvovirus B19 assays: recent advances. Expert Rev Mol Diagn. 2018; 18 (9): 821-32. PubMed PMID: 30028234.

55. Prefumo F, Fichera A, Fratelli N, Sartori E. Fetal anemia: Diagnosis and management. Best Pract Res Clin Obstet Gynaecol. 2019; 58: 2-14. PubMed PMID: 30718211.

56. Voordouw B, Rockx B, Jaenisch T, Fraaij P, Mayaud P, Vossen A, et al. Performance of Zika Assays in the Context of Toxoplasma gondii, Parvovirus B19, Rubella Virus, and Cytomegalovirus (TORCH) Diagnostic Assays. Clin Microbiol Rev. 2019; 33 (1): e00130-18. PubMed PMID: 31826871

57. Bascietto F, Liberati M, Murgano D, Buca D, lacovelli A, Flacco ME, et al. Outcome of fetuses with congenital parvovirus B19 infection: systematic review and meta-analysis. Ultrasound Obstet Gynecol. 2018; 52 (5): 569-76. PubMed PMID: 29785793.

58. Shahgildjan VI, Aleksandrova EP, Kozyrina NV, Shipulina OYu, Dodonova YeA, Shahgildjan NV. Citomegalovirusnaja infekcija u beremennyh i novorozhdennyh: jepidemiologicheskij analiz, novye podhody $\mathrm{k}$ diagnostike $\mathrm{i}$ lecheniju. Akusherstvo ginekologija: novosti, mnenija, obuchenie. 2020; 8 (2): 80-94. DOI: 10.24411/2303-9698-2020-12008. Russian.

59. Shahgildjan VI. Vrozhdennaja citomegalovirusnaja infekcija: aktual'nye voprosy, vozmozhnye otvety. Neonatologija: novosti, mnenija, obuchenie. 2020; 8 (4): 61-72. DOI: https://doi. org/10.33029/2308-2402-2020-8-4-61-72. Russian.

Quindío, Colombia. Ophthalmic Epidemiol. 2021; 28 (3): 258-64. PubMed PMID: 33115293.

5. МКБ 10 - Международная классификация болезней 10-го пересмотра версия: 2019. Доступно по ссылке: https://mkb10.com/index.php?pid=15190 (08.09.2021).

6. Gregg, NM. Congenital Cataract Following German Measles in the Mother. Epidemiol Infect. 1991; 107 (1): iii-xiv.

7. Федеральная служба по надзору в сфере защиты прав потребителей и благополучия человека. Раздел «Документы». Доступно по ссылке: https://www.rospotrebnadzor.ru/ documents/documents.php (08.09.2021).

8. Moodley A, Payton KSE. The Term Newborn: Congenital Infections. Clin Perinatol. 2021; 48 (3): 485-511. PubMed PMID: 34353577.

9. World Health Organization. 2017. [2019-05-07]. Herpes simplex 
virus. Available from: https://www.who.int/news-room/factsheets/detail/herpes-simplex-virus.

10. Van Der Pol B. Type-specific detection of herpes simplex virus type 1 and type 2 using the cobas ${ }^{\oplus}$ HSV 1 and 2 test on the cobas $^{\oplus} 4800$ platform. Expert Rev Mol Diagn. 2016 ; 16 (11): 1145-54. PubMed PMID: 27687862.

11. James SH, Kimberlin DW. Neonatal herpes simplex virus infection: epidemiology and treatment. Clin Perinatol. 2015; 42 (1): 47-59. PubMed PMID: 25677996.

12. Tan MP, Koren G. Chickenpox in pregnancy: revisited. Reprod Toxicol. 2006 ; 21 (4): 410-20. PubMed PMID: 15979274.

13. Smith CK, Arvin AM. Varicella in the fetus and newborn. Semin Fetal Neonatal Med. 2009; 14 (4): 209-17. PubMed PMID: 19097954

14. Sauerbrei A, Wutzler P. Neonatal varicella. J Perinatol. 2001 Dec; 21 (8): 545-9. PubMed PMID: 11774017.

15. Trotta M, Borchi B, Niccolai A, Venturini E, Giaché S, Sterrantino G, et al. Epidemiology, management and outcome of varicella in pregnancy: a 20-year experience at the Tuscany Reference Centre for Infectious Diseases in Pregnancy. Infection. 2018 Oct; 46 (5): 693-9. PubMed PMID: 29766472.

16. Auriti C, De Rose DU, Santisi A, Martini L, Piersigilli F, Bersani I, et al. Pregnancy and viral infections: Mechanisms of fetal damage, diagnosis and prevention of neonatal adverse outcomes from cytomegalovirus to SARS-CoV-2 and Zika virus. Biochim Biophys Acta Mol Basis Dis. 2021 Oct 1; 1867 (10): 166198. PubMed PMID: 34118406.

17. Peyron F, Mc Leod R, Ajzenberg D, Contopoulos-loannidis D, Kieffer F, Mandelbrot L, et al. Congenital Toxoplasmosis in France and the United States: One Parasite, Two Diverging Approaches. PLoS Negl Trop Dis. 2017 Feb 16; 11 (2): e0005222. PubMed PMID: 28207736.

18. Albright CM, Werner EF, Hughes BL. Cytomegalovirus Screening in Pregnancy: A Cost-Effectiveness and Threshold Analysis. Am J Perinatol. 2019 Jun; 36 (7): 678-87. PubMed PMID: 30567003.

19. Федеральный закон от 21 ноября 2011 г. N 323-ФЗ «Об основах охраны здоровья граждан в Российской Федерации» с изменениями и дополнениями. https://base.garant.ru/12191967/ (Доступ 26.03.2021 г.).

20. Приказ Министерства здравоохранения Российской Федерации от 28.02.2019 № 104н "Об утверждении порядка и сроков одобрения и утверждения клинических рекомендаций, критериев принятия научно-практическим советом решения об одобрении, отклонении или направлении на доработку клинических рекомендаций либо решения об их пересмотре». Доступно по ссылке: https://www.garant. ru/products/ipo/prime/doc/72599420/. (Дата обращения: 12.03.2020)

21. Постановление Главного государственного санитарного врача Российской Федерации от 28 января 2021 года № 4 ««Об утверждении санитарных правил и норм СанПиН 3.3686-21 «Санитарно-эпидемиологические требования по профилактике инфекционных болезней»». Доступо по ссылке: https://docs.cntd.ru/document/573660140 (07.09.2021).

22. LeGoff $J$, Péré $H$, Bélec $L$. Diagnosis of genital herpes simplex virus infection in the clinical laboratory. Virol J. 2014; 11: 83. PubMed PMID: 24885431.

23. Pinninti SG, Kimberlin DW. Preventing herpes simplex virus in the newborn. ClinPerinatol. 201441 (4): 945-55. PubMed PMID: 25459782

24. Brown ZA, Selke S, Zeh J, et al. The acquisition of herpes simplex virus during pregnancy. N Engl J Med. 1997; 337 (8): 509-15.

25. Management of Genital Herpes in Pregnancy: ACOG Practice Bulletinacog Practice Bulletin, Number 220. Obstet Gynecol. 2020 May; 135 (5): e193-e202. PubMed PMID: 32332414.

26. Samies NL, James SH. Prevention and treatment of neonatal herpes simplex virus infection. Antiviral Res. 2020 Apr; 176: 104721. PubMed PMID: 32044154.

27. Grupo de Trabajo de Infección Neonatal por virus herpes simplex de la Sociedad Española de InfectologíaPediátrica. Guía de la Sociedad Española de InfectologíaPediátricasobreprevenci ón, diagnóstico y tratamiento de la infección neonatal por virus herpes simplex [The Spanish Society of Paediatric Infectious
Diseases guidelines on the prevention, diagnosis and treatment of neonatal herpes simplex infections]. An Pediatr. 2018 Jul; 89 (1): 64.e1-64.e10. PubMed PMID: 29453157.

28. Sénat MV, Anselem $O$, Picone $O$, Renesme $L$, Sananès $N$, Vauloup-Fellous $C$, et al. Prevention and management of genital herpes simplex infection during pregnancy and delivery: Guidelines from the French College of Gynaecologists and Obstetricians (CNGOF). Eur J Obstet Gynecol Reprod Biol. 2018 May; 224: 93-101. PubMed PMID: 29571124.

29. Ramgopal S, Wilson PM, Florin TA. Diagnosis and Management of Neonatal Herpes Simplex Infection in the Emergency Department. PediatrEmerg Care. 2020 Apr; 36 (4): 196-202. PubMed PMID: 32265379.

30. Fernandes ND, Arya K, Ward R. Congenital Herpes Simplex. In: StatPearls Treasure Island (FL): Stat Pearls Publishing, 2021 Jan. PubMed PMID: 29939674.

31. Shangase N, Kharsany ABM, Ntombela NP, Pettifor A, McKinnon LR. A Systematic Review of Randomized Controlled Trials of School Based Interventions on Sexual Risk Behaviors and Sexually Transmitted Infections Among Young Adolescents in Sub-Saharan Africa. AIDS Behav. 2021 Mar 27. PubMed PMID: 33772695.

32. Otto WR, Myers AL, LaRussa B, Kimberlin DW, Jackson MA. Clinical Markers and Outcomes of Neonates With Herpes Simplex Virus Deoxyribonucleic Acid Persistence in Cerebrospinal Fluid in Disseminated and Central Nervous System Infection. J Pediatric Infect Dis Soc. 2018 May 15; 7 (2): e30-e33. PubMed PMID: 28510722.

33. Davis NL, King CC, Kourtis AP. Cytomegalovirus infection in pregnancy. Birth Defects Res 2017; 109 (5): 336-464.

34. Mussi-Pinhata MM, Yamamoto AY, Aragon DC, et al. Seroconversion for Cytomegalovirus Infection During Pregnancy and Fetal Infection in a Highly Seropositive Population: "The BraCHS Study". J Infect Dis. 2018; 218: 1200.

35. Hughes BL, Gyamfi-Bannerman C. Society for Maternal-Fetal Medicine (SMFM). Diagnosis and antenatal management of congenital cytomegalovirus infection. Am J Obstet Gynecol. 2016; 214 (6): B5-B11.

36. Rawlinson WD, Boppana SB, Fowler KB, Kimberlin DW, et al. Congenital cytomegalovirus infection in pregnancy and the neonate: consensus recommendations for prevention, diagnosis, and therapy. Lancet Infect Dis. 2017; 17 (6): e177-e188.

37. Britt WJ. Congenital human cytomegalovirus infection and the enigma of maternal immunity. J Virol 2017; 91 (15).

38. Luck SE, Wieringa JW, Blázquez-Gamero D, Henneke P, Schuster K, Butler K, et al. Congenital Cytomegalovirus: A European Expert Consensus Statement on Diagnosis and Management. Pediatr Infect Dis J. 2017; 36 (12): 1205-13. PubMed PMID: 29140947.

39. Capretti MG, Lanari M, Tani G, Ancora G, Sciutti R, Marsico C, et al. Role of cerebral ultrasound and magnetic resonance imaging in newborns with congenital cytomegalovirus infection. Brain Dev. 2014; 36 (3): 203-11. PubMed PMID: 23647916.

40. de Vries LS, Gunardi H, Barth PG, Bok LA, Verboon-Maciolek MA, Groenendaal F. The spectrum of cranial ultrasound and magnetic resonance imaging abnormalities in congenital cytomegalovirus infection. Neuropediatrics. 2004 Apr; 35 (2): 113-9. PubMed PMID: 15127310.

41. Desveaux C, Klein J, Leruez-Ville M, et al. Identification of symptomatic fetuses infected with cytomegalovirus using amniotic fluid peptide biomarkers. PloSPathog. 2016; 12: e1005395.

42. Boppana SB, Ross SA, Shimamura M, Palmer AL, Ahmed A, Michaels MG, et al. Saliva polymerase-chain-reaction assay for cytomegalovirus screening in newborns. N Engl J Med. 2011; 364 (22): 2111-8. PubMed PMID: 21631323.

43. Ross SA, Ahmed A, Palmer AL, Michaels MG, Sánchez PJ, Bernstein DI, et al. Detection of congenital cytomegalovirus infection by real-time polymerase chain reaction analysis of saliva or urine specimens. J Infect Dis. 2014; 210 (9): 1415-8. PubMed PMID: 24799600.

44. Eventov-Friedman S, Manor H, Bar-Oz B, Averbuch D, Caplan O, Lifshitz A, et al. Saliva Real-Time Polymerase Chain Reaction for Targeted Screening of Congenital Cytomegalovirus Infection. J Infect Dis. 2019; 220 (11): 1790-6. PubMed PMID: 31310307.

45. Bilavsky E, Watad S, Levy I, Linder N, Pardo J, Ben-Zvi H, et al. 
Positive IgM in Congenital CMV Infection. Clin Pediatr (Phila). 2017; 56 (4): 371-75. PubMed PMID: 28006975.

46. Рогозина Н. В., Васильев В. В., Гринева А. А., Михайлов А. В., Каштанова Т. А., Романовский А. Н. и др. Анте- и постнатальная диагностика и комплексное лечение врожденной цитомегаловирусной инфекции. Рос вестн перинатол и педиатр 2019; 64: (6): 89-93. DOI: 10.21508/10274065-2019-64-6-89-93.

47. Marsico C, Kimberlin D. W. Congenital Cytomegalovirus infection: advances and challenges in diagnosis, prevention and treatment. Ital J Pediatr. 2017; 43: 38. Published online 2017 Apr 17. DOI: 10.1186/s13052-017-0358-8.

48. Ross SA, Ahmed A, Palmer AL, Michaels MG, Sánchez PJ, Bernstein DI, et al. Detection of Congenital Cytomegalovirus Infection by Real-Time Polymerase Chain Reaction Analysis of Saliva or Urine Specimens. The Journal of Infectious Diseases 2014; 210: 1415-8. DOI: 10.1093/infdis/jiu263.

49. Xiong YQ, Tan J, Liu YM, He Q, Li L, Zou K, et al. The risk of maternal parvovirus B19 infection during pregnancy on fetal loss and fetal hydrops: A systematic review and meta-analysis. J ClinVirol. 2019; 114: 12-20. PubMed PMID: 30897374.

50. Шишко Г. А., Ермолович М. А., Самойлович Е. О., Артюшевская М. В., Леонова Е. Ю., Устинович Ю. А. Роль парвовирусной инфекции в перинатальной патологии. Репродуктивное здоровье. Восточная Европа. 2015; 5: 95-102.

51. Attwood LO, Holmes NE, Hui L. Identification and management of congenital parvovirus B19 infection. Prenat Diagn. 2020 Dec; 40 (13): 1722-31. PubMed PMID: 32860469.

52. Salbetti MB, Pedranti MS, Barbero P, Molisani P, Lazzari M, Olivera $\mathrm{N}$, et al. Molecular screening of the human parvoviruses B19 and bocavirus 1 in the study of congenital diseases as applied to symptomatic pregnant women and children. Access Microbiol. 2019; 1 (5): e000037. PubMed PMID: 32974527.

53. Hunter LA, Ayala NK. Parvovirus B19 in Pregnancy: A Case Review. J Midwifery Womens Health. 2021; 66 (3): 385-90. PubMed PMID: 34101977.

54. Gallinella G. The clinical use of parvovirus B19 assays: recent advances. Expert Rev Mol Diagn. 2018; 18 (9): 821-32. PubMed PMID: 30028234.

55. Prefumo F, Fichera A, Fratelli N, Sartori E. Fetal anemia: Diagnosis and management. Best Pract Res Clin Obstet Gynaecol. 2019; 58: 2-14. PubMed PMID: 30718211.

56. Voordouw B, Rockx B, Jaenisch T, Fraaij P, Mayaud P, Vossen A et al. Performance of Zika Assays in the Context of Toxoplasma gondii, Parvovirus B19, Rubella Virus, and Cytomegalovirus (TORCH) Diagnostic Assays. Clin Microbiol Rev. 2019; 33 (1): e00130-18. PubMed PMID: 31826871.

57. Bascietto F, Liberati M, Murgano D, Buca D, lacovelli A, Flacco ME, et al. Outcome of fetuses with congenital parvovirus B19 infection: systematic review and meta-analysis. Ultrasound Obstet Gynecol. 2018; 52 (5): 569-76. PubMed PMID: 29785793.

58. Шахгильдян В. И., Александрова Е. П., Козырина Н. В., Шипулина О. Ю., Додонова Э. А., Шахгильдян Н. В. Цитомегаловирусная инфекция у беременных и новорожденных: эпидемиологический анализ, новые подходы к диагностике и лечению. Акушерство и гинекология: новости, мнения, обучение. 2020; 8 (2): 80-94. DOI: 10.24411/2303-9698-2020-12008.

59. Шахгильдян В. И. Врожденная цитомегаловирусная инфекция: актуальные вопросы, возможные ответы. Неонатология: новости, мнения, обучение. 2020; 8 (4): 61-72. DOI: https://doi.org/10.33029/2308-2402-2020-8-4-61-72. 